\title{
Lactose intolerance among severely malnourished children with diarrhoea admitted to the nutrition unit, Mulago hospital, Uganda
}

\author{
Richard Nyeko*1, Israel Kalyesubula2 ${ }^{2}$ Edison Mworozi² and Hanifa Bachou²
}

\begin{abstract}
Background: Lactose intolerance is a common complication of diarrhoea in infants with malnutrition and a cause of treatment failure. A combination of nutritional injury and infectious insults in severe protein energy malnutrition reduces the capacity of the intestinal mucosa to produce lactase enzyme necessary for the digestion of lactose.

The standard management of severe malnutrition involves nutritional rehabilitation with lactose-based high energy formula milk. However, some of these children may be lactose intolerant, possibly contributing to the high rate of unfavorable treatment outcomes. This study was therefore designed to establish the prevalence of lactose intolerance and associated factors in this population.

Methods: A descriptive cross sectional study involving 196 severely malnourished children with diarrhoea aged 3-60 months was done in Mwanamugimu Nutrition Unit (MNU), Mulago hospital between October 2006 and February 2007.

Results: During the study period, 196 severely malnourished children with diarrhoea were recruited, 50 (25.5\%) of whom had evidence of lactose intolerance (stool reducing substance $\geq 1+[0.5 \%]$ and stool pH $<5.5$ ) and it occurred more commonly in children with kwashiorkor $27 / 75$ (36.0\%) than marasmic-kwashiorkor 6/25 (24.0\%) and marasmus $17 / 96$ (17.7\%). Oedematous malnutrition ( $p=0.032)$, perianal skin erosion $(p=0.044)$, high mean stool frequency $(p=$ $<0.001)$ and having $\geq 2$ diarrhoea episodes in the previous 3 months $(p=0.007)$ were the independent predictors of lactose intolerance.

Other factors that were significantly associated with lactose intolerance on bi-variate analysis included: young age of 312 months; lack of up to-date immunization; persistent diarrhoea; vomiting; dehydration, and abdominal distension. Exclusive breastfeeding for less than 4 months and worsening of diarrhoea on initiation of therapeutic milk were the other factors.

Conclusions: The prevalence of lactose intolerance in this study setting of $25.5 \%$ is relatively high. Routine screening by stool $\mathrm{pH}$ and reducing substances should be performed especially in the severely malnourished children with diarrhoea presenting with oedematous malnutrition, perianal skin erosion, higher mean stool frequency and having had $\geq 2$ diarrhoea episodes in the previous 3 months.

Use of lactose-free diets such as yoghurt should be considered for children found to have evidence of lactose intolerance and whose response on standard therapeutic milk formula is poor.
\end{abstract}

\section{Background}

Lactose intolerance is a common complication of diarrhoea in infants with malnutrition [1], and a cause of

* Correspondence: richard_nyeko@yahoo.com

1 Department of Paediatrics and Child Health, St. Mary's hospital Lacor, Gulu, Uganda P.O Box 180, Gulu, Uganda

Full list of author information is available at the end of the article

treatment failure $[2,3]$. Prevalences of secondary lactose intolerance have been reported to range from $26 \%$ to as high as $100 \%$ of affected children in some patients in different settings [4-6]. Lactase activity is reduced in many patients with kwashiorkor even at early ages, and carbohydrate intolerance occurs more frequently in children 
with kwashiorkor (48.3\%) than in those with marasmus (15\%), marasmic-kwashiorkor (20\%) and healthy controls (23.5\%) [7]. Kwashiorkor is also associated with variable degrees of malabsorption that complicate the nutritional rehabilitation of the patients. As a consequence, patients with this form of malnutrition also have vitamin and mineral depletion of variable severity and this contributes to further damage to their small intestinal mucosa and to the abnormal proliferation of bacteria in their gut and to the appearance of immune deficiencies.

Children with severe protein-energy malnutrition commonly have a reduced activity of intestinal lactase, the enzyme responsible for the digestion of lactose [8,9], and it has been suggested that feeding this disaccharide can retard nutritional recovery [10]. Secondary lactase deficiency can present at any age but is more common in infancy $[11,12]$. This contrasts with the risks in normal children as demonstrated by Gabr and colleagues in Egypt: $12 \%$ in the age group 6 months to 2 years, $32 \%$ in the age group 2-5 years, $32 \%$ in the age group 5-9 years, and $80 \%$ in the age group $9-12$ years [13].

The manifestations of lactose intolerance are watery acidic stools, abdominal distension and excessive flatus [14]. Perianal skin erosion is also observed frequently and is caused by contact of acidic, watery stools with the skin $[15,16]$. Lactose intolerance rates are significantly increased in children with a history of recent diarrhoea [17], and dehydration due to osmotic diarrhoea may be common [14].

In one study, milk intolerance presenting as diarrhoea was significantly more common in children with giardiasis [18]. Similarly, Pettoello and colleagues in Italy concluded that the occurrence of lactose malabsorption of nutritional relevance was common in children suffering or having suffered from giardiasis (45\%) [19].

The mortality of severely malnourished children is very high (24\% in the setting in which this study was carried out) [20]. Part of this is due to dehydration which is aggravated by lactase deficiency. Little is known concerning the magnitude of lactose intolerance in this study setting, yet the standard of care involves the use of lactosebased high energy formula milk. This study was therefore designed to establish the prevalence of lactose intolerance and associated factors in this population.

\section{Methods}

\section{Study setting}

The study was undertaken at Mwanamugimu Nutrition Unit (MNU) of Mulago hospital, Kampala, the national referral and teaching hospital for Makerere University College of Health Sciences. The department of Paediatrics and Child Health is one of the largest departments in the hospital, admitting over 10000 children annually. The MNU is a 72-bed capacity unit specialized in managing children with severe acute malnutrition with an average monthly admission of 50-70 patients, about $50 \%$ of whom present with diarrhoea, and this varies according to seasons.

\section{Study design}

This was a descriptive cross-sectional study. The sample size was calculated using the Leslie Kish formula [21] and a prevalence of $15 \%$ as found by Tolboom in marasmic Besotho children [7].

The study population consisted of severely malnourished children with diarrhoea aged 3-60 months admitted to $\mathrm{MNU}$, Mulago hospital during the study period. The WHO classification of severe malnutrition was used: A severely malnourished child was one whose weight-forheight was less than -3SD or less than $70 \%$ of the median National Centre for Health Statistics (NCHS)/WHO reference median (severe wasting), or who had bilateral pitting pedal oedema. The Wellcome classification was used to classify a malnourished child as having kwashiorkor (defined as weight-for-age between $60-80 \%$ of the median in the presence of bilateral pitting pedal edema), marasmus (weight-for-age $<60 \%$ in the absence of edema), or marasmic-kwashiorkor (weight-for-age $<60 \%$ in the presence of bilateral pitting pedal edema). Children who were already on modified lactose-free diet were excluded.

\section{Data collection/study procedure}

The authors of this study explored the incidence of lactose intolerance in the study population on the basis of a pre-coded and pre-tested structured questionnaire and tests in fresh stools of the participants at least 24 hours after initiating standard lactose-based therapeutic milk diet, with measurements of stool $\mathrm{pH}$ and presence of reducing substances in faeces. The test was considered positive if stool reducing substances were equal to or more than $1+(=0.5 \%)$ and stool $\mathrm{pH}$ less than 5.5 . Stool microscopy was performed for fat globules, ova/cysts, parasites (giardiasis), pus cells and yeasts (Candida albicans). Recruitment into the study was by consecutive enrollment of children who fulfilled the inclusion criteria. A quick assessment for complications including hypothermia, dehydration and/or shock and severe infections was done by the principal investigator. Any necessary resuscitation management was instituted before recruitment into the study. The purpose of the study was explained to the parents/caretakers, including pretest HIV counseling and informed consent were obtained for participation in the study. Children whose caretakers declined HIV test were still recruited if they were willing to participate and consented for the study.

\section{Laboratory procedure}

Blood samples were obtained for an HIV test. Post test counseling was done as soon as results were obtained. All 
children found to be HIV positive were referred to the Paediatric Infectious Disease Clinic (PIDC) for appropriate management and their mothers referred to the adult clinic for appropriate care as well. The HIV test was done under an arrangement of routine counseling and testing (RCT) that was already operational in the unit. CD4 counts were not done.

Stool $\mathrm{pH}$ was tested using narrow range $\mathrm{pH}$ papers after dissolution of the fresh stool specimen in distilled water, while presence of reducing substance was tested by use of Benedict's solution.

Quality control was ensured by using one qualified laboratory technologist to carry out the analysis of samples using an established reputable laboratory of Mulago National Referral Hospital.

\section{Data management and analysis}

Data was coded and entered into a computerized database using Epidata 3.1. All data collected was crosschecked for completeness and accuracy and cleaned before analysis. The analysis was done using the Statistical Package for Social Sciences (SSPS II) software. Categorical variables were summarized as frequencies and proportions, while continuous variables as means, median and standard deviations (SD).

In the bi-variate analysis, odds ratios, 95\% confidence interval (CI), and chi-square test were used to measure the strength of association between the factors considered and the dependent variable, while the student's t-test was used for continuous variables.

Multivariate analysis using logistic regression was used to determine the factors that were independently associated with lactose intolerance. P-value $<0.05$ was considered for statistical significance. Results were summarized in texts, tables and bar graphs.

\section{Ethical considerations}

The study was approved by the Ethics and Research Committee of the School of Health Sciences, Makerere University, and the Uganda National Council for Science and Technology. Voluntary informed consent was obtained from the parents/caretakers before participating in the study. Confidentiality was observed throughout the study. All children found to be HIV positive were referred to PIDC and their mothers to the adult HIV clinic for further management.

\section{Results}

The study included 196 children 3-60 months of age (mean age 15.5 months and median 12 months). Sixty four $(32.7 \%)$ of the study children were HIV positive and only one of them was on antiretroviral therapy, 113 (57.7\%) were males and only 50.0\% (98/196) had up todate immunization.
The prevalence of lactose intolerance was $25.5 \%$ by these criteria and was highest among the children in the age group 3-12 months (68.0\%), with $90 \%$ of the cases occurring in the first two years of life. The prevalence then markedly reduced after 24 months of age, a trend that mirrors the prevalence of severe malnutrition (Figure 1).

Lactose intolerance occured more commonly in children with kwashiorkor $\{27 / 75(36.0 \%),[p=0.011]\}$ than marasmic-kwashiorkor $\{6 / 25 \quad(24.0 \%),[\mathrm{p}=1.000]\}$ and marasmus $\{17 / 196$ (17.7\%), [p=0.021] $\}$ (Table 1).

At bivariate analysis, child's age and immunization status (Table 2), duration of exclusive breastfeeding and effect of starting therapeutic milk (Table 3) were all significantly associated with lactose intolerance. Also significant were duration of diarrhoea, diarrhoea episodes in the previous 3 months and stool frequency (Table 4). Vomiting, body temperature, hydration status, presence of oedema, perianal skin erosion, and abdominal distension were the other significant clinical characteristics (Table 5).

At multivariate analysis, oedematous malnutrition, perianal skin erosion, high mean stool frequency and having two or more diarrhoea episodes in the previous 3 months were the independent predictors of lactose intolerance (Table 6).

\section{Discussion}

The $25.5 \%$ prevalence of lactose intolerance in the 196 severely malnourished children with diarrhoea accords with a previous finding in a Senegalese study of $26 \%$ [4], but lower than that reported in other studies [5,6], a difference that might be explained by the difference in sample size and study population. Nonetheless, the prevalence of lactose intolerance in the current study is still significantly high, a fact that could be a plausible contributing factor to the unfavorable outcome that has

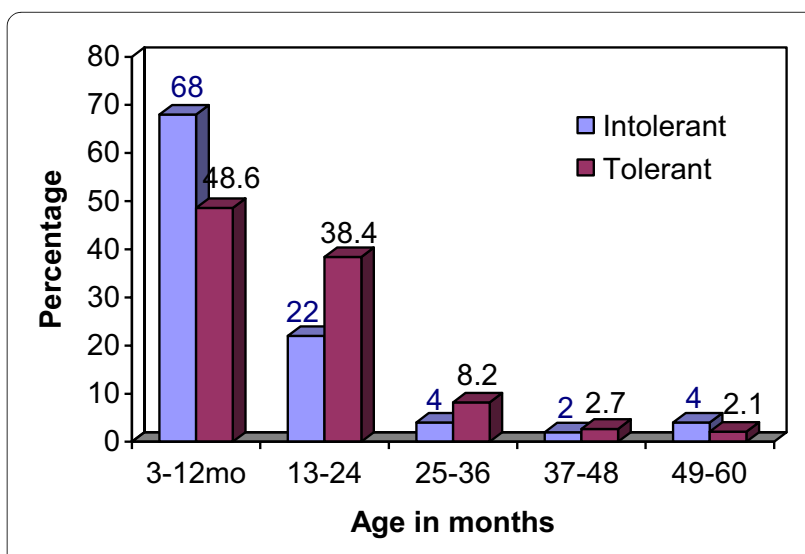

Figure 1 Age distribution by lactose tolerance. 
Table 1: Lactose tolerance by type of malnutrition

\begin{tabular}{|c|c|c|c|c|c|}
\hline Characteristics & $\begin{array}{l}\text { Lactose } \\
\text { intolerant } \\
\mathrm{N}=\mathbf{5 0}(\%)\end{array}$ & $\begin{array}{l}\text { Lactose tolerant } \\
N=146(\%)\end{array}$ & OR & $95 \% \mathrm{Cl}$ & p-value \\
\hline \multicolumn{6}{|l|}{ Kwashiorkor: } \\
\hline Yes & $27(36.0)$ & $48(64.0)$ & 2.40 & $1.25-4.61$ & $0.011 *$ \\
\hline No & $23(19.0)$ & $98(81.0)$ & & & \\
\hline \multicolumn{6}{|c|}{ \#Marasmic-kwash: } \\
\hline Yes & $6(24.0)$ & 19(76.0) & 0.91 & $0.34-2.43$ & 1.000 \\
\hline No & $44(25.7)$ & $127(74.3)$ & & & \\
\hline \multicolumn{6}{|l|}{ Marasmus: } \\
\hline Yes & $17(17.7)$ & $79(82.3)$ & 0.44 & $0.22-0.85$ & $0.021^{*}$ \\
\hline No & $33(33.0)$ & $67(67.0)$ & & & \\
\hline
\end{tabular}

*P-value significant $(<0.05)$, OR = Odd's ratio, $\mathrm{Cl}=95 \%$ confidence interval,

\# Marasmic-kwashiorkor

Table 2: Baseline characteristics of the study population and lactose intolerance

\begin{tabular}{|c|c|c|c|c|c|}
\hline Characteristics & $\begin{array}{l}\text { Lactose } \\
\text { intolerant } \\
\mathrm{N}=\mathbf{5 0}(\%)\end{array}$ & $\begin{array}{l}\text { Lactose tolerant } \\
N=146(\%)\end{array}$ & OR & $95 \% \mathrm{Cl}$ & p-value \\
\hline \multicolumn{6}{|l|}{ Sex: } \\
\hline Male & $27(23.9)$ & $86(76.1)$ & 0.82 & $0.43-1.56$ & 0.545 \\
\hline Female & $23(27.7)$ & $60(72.3)$ & & & \\
\hline \multicolumn{6}{|l|}{ Age in months: } \\
\hline $3-12$ & $34(32.4)$ & $71(67.6)$ & 2.25 & $1.14-4.42$ & $0.018 *$ \\
\hline Above 12 & $16(17.6)$ & $75(82.4)$ & & & \\
\hline \multicolumn{6}{|l|}{ Birth order: } \\
\hline First & $18(31.0)$ & $40(69.0)$ & 1.49 & $0.75-2.95$ & 0.250 \\
\hline$\geq$ Second & $32(23.2)$ & $106(76.8)$ & & & \\
\hline \multicolumn{6}{|l|}{ Immunization status: } \\
\hline Not up to-date & $39(39.8)$ & $59(60.2)$ & 5.23 & $2.48-11.03$ & $<0.001 *$ \\
\hline Up to-date & $11(11.2)$ & $87(88.8)$ & & & \\
\hline \multicolumn{6}{|l|}{$\Delta$ Measles in the previous 3 months: } \\
\hline Yes & $18(35.3)$ & $33(64.7)$ & 1.90 & $0.94-3.83$ & 0.070 \\
\hline No & $31(22.3)$ & 108(77.7) & & & \\
\hline \multicolumn{6}{|l|}{ १HIV status: } \\
\hline HIV+ve & $19(29.7)$ & $45(70.3)$ & 1.42 & $0.72-2.80$ & 0.315 \\
\hline HIV-ve & $28(23.0)$ & $94(77.0)$ & & & \\
\hline
\end{tabular}

*P-value significant $(<0.05), \mathrm{OR}=$ Odd's ratio, $\mathrm{Cl}=95 \%$ confidence interval

$\Delta$ Some caretakers were unsure, hence the ones considered (190/196) do not add up to 196

१ Only those with confirmed HIV status were considered (186/196) hence they do not add up to 196 . HIV by rapid test for age $\geq 18$ months and DNA PCR for age $<18$ months. 
Table 3: Feeding practices associated with lactose intolerance

\begin{tabular}{|c|c|c|c|c|c|}
\hline Characteristics & $\begin{array}{l}\text { Lactose } \\
\text { intolerant } \\
\mathrm{N}=50(\%)\end{array}$ & $\begin{array}{l}\text { Lactose tolerant } \\
N=146(\%)\end{array}$ & OR & $95 \% \mathrm{Cl}$ & p-value \\
\hline \multicolumn{6}{|l|}{$\begin{array}{l}\Delta \text { Still } \\
\text { breastfeeding: }\end{array}$} \\
\hline Yes & $11(24.4)$ & $34(75.6)$ & 0.87 & $0.40-1.90$ & 0.719 \\
\hline No & $34(27.2)$ & $91(72.8)$ & & & \\
\hline \multicolumn{6}{|l|}{ \#Duration of EBF: } \\
\hline$<4$ months & $25(35.7)$ & $45(64.3)$ & 2.24 & $1.16-4.33$ & $0.015^{*}$ \\
\hline$\geq 4$ months & $25(19.8)$ & $101(80.2)$ & & & \\
\hline \multicolumn{6}{|l|}{$\begin{array}{l}\text { Ever had } \\
\text { problems with } \\
\text { cow's milk: }\end{array}$} \\
\hline Yes & $3(50.0)$ & $3(50.0)$ & 3.04 & $0.59-15.59$ & $0.175 \psi$ \\
\hline No & $47(24.7)$ & $143(75.3)$ & & & \\
\hline \multicolumn{6}{|l|}{$\begin{array}{l}\text { "Effect of } \\
\text { starting } \\
\text { therapeutic } \\
\text { milk: }\end{array}$} \\
\hline $\begin{array}{r}\text { Diarrhea } \\
\text { worsened }\end{array}$ & $25(35.2)$ & $46(64.8)$ & 2.88 & $1.41-5.86$ & $0.003^{*}$ \\
\hline No effect & $17(15.9)$ & $90(84.1)$ & & & \\
\hline \multicolumn{6}{|l|}{$\begin{array}{l}\text { Therapeutic } \\
\text { milk: }\end{array}$} \\
\hline F75 & $41(25.6)$ & $119(74.4)$ & 1.03 & $0.45-2.38$ & 0.938 \\
\hline F100 & $9(25.0)$ & $27(75.0)$ & & & \\
\hline
\end{tabular}

*P-value significant $(<0.05), \mathrm{OR}=$ Odd's ratio, $\mathrm{Cl}=95 \%$ confidence interval

$\Delta$ Only children in the breastfeeding age range (3-24 months) were considered; hence they do not add up to 196. \# Duration of exclusive breastfeeding, $\Psi$ Fisher's Exact Test

I Only for those who had diarrhoea at admission, hence they do not add up to $196,(178 / 196)$.

remained a challenge in the management of severely malnourished children, more so those with diarrhoea.

Evidence of lactose intolerance occurred more frequently in children with kwashiorkor $27 / 75$ (36.0\%) than in those with marasmic-kwashiorkor $6 / 25(24.0 \%)$ and marasmus 17/96 (17.7\%), a finding consistent with that by Tolboom and colleagues [7]. This might not be surprising and seems to reinforce the fact that kwashiorkor is associated with variable degrees of malabsorption, with protein and energy as well as vitamin and mineral deficiencies of variable severity that contributes to intestinal mucosal damage, in addition to oxidative stress. Failure of the intestinal barrier from bacterial overgrowth and passage of lipopolysaccharide to the systemic circulation and uncontrolled stimulation of the inflammatory mechanisms probably also have a part to play.

Most children (68\%) with lactose intolerance were infants 3-12 months, a finding consistent with several other studies $[3,12]$. This, however, contrasts with the risks in normal children as demonstrated by Gabr and colleagues in Egypt [13], a difference attributed to the fact that in normal children, lactose intolerance is mainly due to primary lactase deficiency which increases with age (becomes apparent by 5 years of age), as opposed to secondary lactase deficiency which, though can present at any age, is more common in infancy [11]. In our study, there was a gradual decrease in the prevalence of lactose intolerance from $68 \%$ in the age group $3-12$ to $2 \%$ in the $37-48$ age groups, with a slight rise thereafter to $4 \%$ among the 49-60 age groups which could be attributed to underlying primary lactose intolerance which becomes apparent by 5 years of age, possibly aggravated by the diarrhoea and severe malnutrition.

Children with lactose intolerance were more likely to have a higher mean stool frequency ( $\geq 8$ motions in 24 hour period) [ $<<0.001]$, a finding consistent with that by Ozmert and colleagues in Turkey [12]. This is not surprising since unabsorbed lactose that is not metabolized by 
Table 4: Diarrhoea characteristics associated with lactose intolerance

\begin{tabular}{|c|c|c|c|c|c|}
\hline Characteristics & $\begin{array}{l}\text { Lactose } \\
\text { intolerant } \\
\mathrm{N}=50(\%)\end{array}$ & $\begin{array}{l}\text { Lactose tolerant } \\
N=146(\%)\end{array}$ & OR & $95 \% \mathrm{Cl}$ & p-value \\
\hline \multicolumn{6}{|l|}{ Duration: } \\
\hline$\geq 14$ days & $26(34.2)$ & $50(65.8)$ & 2.08 & $1.08-3.99$ & $0.026^{*}$ \\
\hline$<14$ days & $24(20.0)$ & $96(80.0)$ & & & \\
\hline \multicolumn{6}{|l|}{ Watery stool: } \\
\hline Yes & $34(26.8)$ & $93(73.2)$ & 1.21 & $0.61-2.40$ & 0.583 \\
\hline No & $16(23.2)$ & $53(76.8)$ & & & \\
\hline \multicolumn{6}{|l|}{ Blood in stool: } \\
\hline Yes & $2(40.0)$ & $3(60.0)$ & 1.99 & $0.32-12.24$ & $0.603 \Psi$ \\
\hline No & $48(25.1)$ & $143(74.9)$ & & & \\
\hline \multicolumn{6}{|l|}{$\begin{array}{l}\text { Antibiotic use } \\
\text { during } \\
\text { diarrhoea: }\end{array}$} \\
\hline Yes & $25(24.8)$ & $76(75.2)$ & 0.92 & $0.48-1.75$ & 0.802 \\
\hline No & $25(26.3)$ & 70(73.7) & & & \\
\hline \multicolumn{6}{|l|}{$\begin{array}{l}\text { Use of local } \\
\text { herbs: }\end{array}$} \\
\hline Yes & $13(26.0)$ & $37(74.0)$ & 1.040 & $0.50-2.16$ & 0.927 \\
\hline No & $37(25.3)$ & 109(74.7) & & & \\
\hline \multicolumn{6}{|l|}{$\begin{array}{l}\text { Diarrhea } \\
\text { episodes in the } \\
\text { previous } 3 \text { mo }\end{array}$} \\
\hline$\geq 2$ & $40(47.1)$ & $45(52.9)$ & 8.98 & $4.13-19.52$ & $<0.001^{*}$ \\
\hline One & $10(9.0)$ & $101(91.0)$ & & & \\
\hline \multicolumn{6}{|l|}{$\begin{array}{l}\text { Fat globules in } \\
\text { stool }\end{array}$} \\
\hline Yes & $3(60.0)$ & $2(40.0)$ & 4.60 & $0.75-28.34$ & $0.106 \Psi$ \\
\hline No & $47(24.6)$ & $144(75.4)$ & & & \\
\hline \multicolumn{6}{|l|}{$\begin{array}{l}\text { Yeasts in stool } \\
\text { (Candida } \\
\text { albicans): }\end{array}$} \\
\hline Yes & $29(27.6)$ & $76(72.4)$ & 1.27 & $0.67-2.43$ & 0.467 \\
\hline No & $21(23.1)$ & $70(76.9)$ & & & \\
\hline \multicolumn{6}{|l|}{ Pus cells in stool: } \\
\hline Yes & $6(20.0)$ & $24(80.0)$ & 0.693 & $0.27-1.81$ & 0.452 \\
\hline No & $44(26.5)$ & $122(73.5)$ & & & \\
\hline $\begin{array}{l}\text { शFrequency of } \\
\text { stool in } 24 \mathrm{hrs:}\end{array}$ & $9.48(2.35)$ & $5.81(2.20)$ & & & $<0.001 *$ \\
\hline
\end{tabular}

*P-value significant $(<0.05)$, OR = Odd's ratio, $\mathrm{Cl}=95 \%$ confidence interval,

I Student t-test used for mean stool frequencies (standard deviations). $\psi$ Fisher's Exact Test 
Table 5: Clinical characteristics of the severely malnourished children

\begin{tabular}{|c|c|c|c|c|c|}
\hline Characteristics & $\begin{array}{l}\text { Lactose } \\
\text { intolerant } \\
\mathrm{N}=\mathbf{5 0}(\%)\end{array}$ & $\begin{array}{l}\text { Lactose tolerant } \\
\mathrm{N}=146(\%)\end{array}$ & OR & $95 \% \mathrm{Cl}$ & p-value \\
\hline History of fever & $31(62))$. & $92(63.0)$ & 0.96 & $0.49-1.86$ & 0.898 \\
\hline History of vomiting & $35(70.0)$ & $76(52.1)$ & 2.15 & $1.08-4.27$ & $0.027^{*}$ \\
\hline History of cough & $35(70.0)$ & $116(79.5)$ & 0.60 & $0.29-1.25$ & 0.170 \\
\hline $\begin{array}{l}\text { Temperature } \\
\left(\geq 37.5^{\circ} \mathrm{C}\right)\end{array}$ & $10(20.0)$ & $41(28.1)$ & 0.64 & $0.29-1.40$ & 0.261 \\
\hline Temperature $\left(\leq 35^{\circ} \mathrm{C}\right)$ & $12(24.0)$ & $10(6.8)$ & 4.30 & $1.72-10.70$ & $0.001 *$ \\
\hline Oedema & $33(66.0)$ & $67(45.9)$ & 2.29 & $1.17-4.47$ & $0.014^{*}$ \\
\hline Severe pallor & $1(2.0)$ & $3(2.1)$ & 0.97 & $0.10-2.40$ & $1.000 \Psi$ \\
\hline Dehydration & $31(62.0)$ & $60(41.1)$ & 2.34 & $1.21-4.52$ & $0.011 *$ \\
\hline Oral thrush & $11(22.0)$ & $38(26.0)$ & 0.80 & $0.37-1.72$ & 0.570 \\
\hline Lymphadenopathy & $4(8.0)$ & $11(7.5)$ & 1.07 & $0.32-3.52$ & $1.000 \psi$ \\
\hline Perianal erosion & $35(70.0)$ & $28(19.2)$ & 9.83 & $4.73-20.44$ & $<0.001 *$ \\
\hline $\begin{array}{l}\text { Abdominal } \\
\text { distension }\end{array}$ & $20(40.0)$ & $24(16.4)$ & 3.39 & $1.66-6.93$ & $0.001 *$ \\
\hline Hepatomegally & $21(42.0)$ & $47(32.2)$ & 1.53 & $0.79-2.95$ & 0.209 \\
\hline Splenomegally & $4(8.0)$ & $8(5.5)$ & 1.50 & $0.43-5.21$ & $0.506 \Psi$ \\
\hline
\end{tabular}

*P-value significant $(<0.05), \mathrm{OR}=$ Odd's ratio, $\mathrm{Cl}=95 \%$ confidence interval, $\psi$ Fisher's exact test

the colonic bacteria to organic acids would remain in the colonic lumen and lead to osmotic diarrhoea. Furthermore, undigested lactose may attract such an amount of water in the jejunum-ileum that the colon cannot handle, with the speed of transit also a contributing factor in the whole process.

High prevalence of lactose intolerance among children having had two or more diarrhoea episodes in the previous 3 months as found in this study has also been reported elsewhere [17]. Recurrent episodes of diarrhoea result in repeated disruption of the intestinal villi with shortened regeneration and maturation time, predisposing to intestinal lactase deficiency.

Lactose intolerance was more likely in children with persistent diarrhoea (34.2\%) compared to acute diarrhoea
(20.0\%). Fagundes-Neto and colleagues in Brazil reported a similar finding (33.3\% and $18.2 \%$ in persistent and acute diarrhoea respectively) [5]. This supports the observation that the lactase enzyme is localized to the tips of the intestinal villi, a factor of clinical importance when considering the effect of diarrhoeal illness on the ability to tolerate lactose. Persistent diarrhoea also results in a more prolonged and extensive damage of the intestinal mucosa and the immature epithelial cells that replace these are often lactase deficient, leading to secondary lactase deficiency and lactose malabsorption [11]. Conversely, lactose intolerance prolongs and increases the severity of diarrhoea [15].

Thirty five children (70\%) with lactose intolerance presented with perianal skin erosion $(\mathrm{p}<0.001)$, a finding

Table 6: Logistic regression model for factors independently predicting lactose intolerance

\begin{tabular}{|c|c|c|c|}
\hline Characteristics & Odd Ratio & $95 \% \mathrm{Cl}$ & p-value \\
\hline Immunization status & 2.60 & $0.85-7.93$ & 0.093 \\
\hline $\begin{array}{l}\text { Diarrhea episodes in previous } \\
3 \text { months }\end{array}$ & 4.88 & $1.53-15.55$ & $0.007^{*}$ \\
\hline Oedema & 3.40 & $1.11-10.40$ & $0.032 *$ \\
\hline Perianal erosion & 3.07 & $1.03-9.16$ & $0.044^{*}$ \\
\hline Frequency of stool/24 hrs & 0.59 & $0.48-0.74$ & $<0.001 *$ \\
\hline
\end{tabular}

* P-value significant $(<0.05)$, $\mathrm{OR}=$ Odd's ratio, $\mathrm{Cl}=95 \%$ confidence interval 
that has been documented [15]. In the presence of lactose intolerance, unabsorbed lactose gets metabolized by the colonic bacterial flora to organic acids and this is responsible for perianal skin erosion in children with diarrhoea [16].

While other studies have reported significant association of lactose intolerance with giardiasis $[18,19]$, only one child in the current study was found to have giardiasis and she had no evidence of lactose intolerance. Possibly, this was because of a less sensitive method used (wet stool preparation), as the 'string test' of duodenal contents would have been more preferable. Six of the study participants had Cryptosporidia on modified ZN stain, only one of whom had evidence of lactose intolerance and this was not statistically significant. Similarly, in one patient an enteropathogen (salmonella non-typhi) was detected in stool cultures, with no evidence of lactose intolerance. None but one of the HIV positive patients in the study had been started on antiretroviral treatment during the study and she had no evidence of lactose intolerance.

Our study had limitations in that we did not use the breath hydrogen test which is the gold standard because it is expensive, cumbersome to use on a large scale and requires the patient to fast, in addition to use of a lactose load (procedures not desirable in severely malnourished children on highly regulated dietary management). It was not possible to exclude pre-existing/primary disturbances of lactose digestion, including chronic environmental entropathies. Other associated food allergies could not also be excluded. It was also not possible to determine a causal relationship between the different factors and lactose intolerance as this required a different study design.

\section{Conclusions}

The prevalence of lactose intolerance in severely malnourished children with diarrhoea in the study setting of $25.5 \%$ is relatively high, especially in the $3-12$ months age group. Clinical predictors of lactose intolerance in severely malnourished children included oedematous malnutrition, perianal skin erosion, higher mean stool frequency and having $\geq 2$ diarrhoea episodes in the previous 3 months. Lactose intolerance should be considered and routine screening by stool $\mathrm{pH}$ and reducing substance undertaken in these children.

Use of lactose-free diets such as yoghurt should be considered for children found to have evidence of lactose intolerance and whose response on the standard therapy is poor.

\section{Conflict of interests}

The authors declare that they have no competing interests.

\section{Abbreviations}

MNU: Mwanamugimu Nutrition Unit; PIDC: Paediatric Infectious Disease Clinic HIV: Human Immunodeficiency Virus; RCT: Routine Counseling and Testing; WHO: World Health Organization; ZN: Ziehl-Neelsen

\section{Authors' contributions}

RN was the initiator of the study and contributed to the study design, data collection, and interpretation of results. IK, EM and HB contributed to the study design, interpretation of results and drafting of the manuscript. All authors have read and approved the final manuscript

\section{Acknowledgements}

We acknowledge all the staff of the nutrition unit and the department of Paediatrics, Mulago hospital for their support and inputs towards this study. A special tribute goes to the parents/caretakers and the children who participated in this study.

\section{Author Details}

'Department of Paediatrics and Child Health, St. Mary's hospital Lacor, Gulu, Uganda P.O Box 180, Gulu, Uganda and 2Department of Paediatrics and Child Health, College of Health Sciences, Makerere University, Kampala, Uganda, P.O Box 7072, Kampala, Uganda

Received: 19 March 2009 Accepted: 6 May 2010

Published: 6 May 2010

\section{References}

1. Lifshitz F, Coello-Ramirez P, Guteirrez-Topete G, Cornado-Cornet MC Carbohydrates intolerance in infants with diarrhoea. Journal of Pediatrics 1971, 79(5):760-7.

2. Penny ME, Paredes P, Brown KH: Clinical and nutritional consequences of lactose feeding during persistent postenteritis diarrhoea. Paediatrics 1989, 84(5):835-44.

3. de-Andrade JA, de-Olivier JO, Fagundes-Neto U: Acute diarrhoea and malnutrition: Lethality Risk in hospitalized infants. J Am Coll Nutr 1999, 18(4):303-308.

4. Beau JP, Fontaine O, Garenne M: Management of malnourished children with acute diarrhoea and sugar intolerance. J Trop Pediatr 1989, 35(6):281-4

5. Fagundes-Neto U, Viaro T, Lifshitz F: Tolerance to glucose polymers in malnourished infants with diarrhoea and disaccharide intolerance. Am J Clin Nutr 1985, 41(2):228-34.

6. Fajardo LF, Leal H, Victoria F, Gonzalez CE: Milk intolerance in Colombian children, its prevalence and relation to lactose malabsorption. Arch Latinoam Nutr 1979, 29(3):329-39.

7. Tolboom JJ, Ralitapole-Maruping AP, Mothebe M, Kabir H, Molatseli P Fernandes J: Carbohydrates malabsorption in children with severe protein energy malnutrition. Trop Geogr Med 1984, 36(4):355-65.

8. James WPT: Jejunal disaccharide activities in children with marasmus and with kwashiorkor. Arch Dis Child 1971, 46:218-20.

9. Bowie MD, Brinkman GL, Hansen JDL: Acquired disaccharide intolerance in malnutrition. Journal of Pediatrics 1965, 66:1083-91.

10. Lifshitz F: Acquired carbohydrate intolerance in children: clinical manifestations and therapeuric recommendations. The Johns Hopkins University Press; 1981:80-90

11. Melvin BH: Lactose intolerance in infants, children, and adolescents. Pediatrics 2006, 118(3):1279-1286.

12. Ozmert E, Yurdakok K, Aslan D, Yalçin SS, Yardim M: Clinical characteristics of transient glucose intolerance during acute diarrhoea. Acta Paediatr 1999, 88:1071-3.

13. Gabr M, El-Beheiry F, Soliman AA, El-Mougy M, El-Akkad N: Lactose intolerance in normal Egyptian infants and children and in protein calorie malnutrition. Gaz Egypt Paediatr Assoc 1977, 26(1):27-33.

14. Lee Way-Seah: Lactose intolerance. Dietary restrictions; 11 .

15. Chandrika R, Anurag T, Radhakrishna H, Anand CV: Thin layer chromatography in children with sugar intolerance in acute diarrheoa. Indian Journal of Gastroenterology 2006, 25:103.

16. Shaw AD, Davies GJ: Lactose intolerance: problems in diagnosis and treatment. J Clin Gastroenterol 1999, 28:208.

17. Brown $\mathrm{KH}$, Parry L, Khatun M, Ahmed G: Lactose malabsorption in Bangladeshi village children: relation with age, history of recent 
diarrhoea, nutritional status, and breast feeding. Am J Clin Nutr 1979, 32(9):1962-9.

18. Tolboom JJ, Kabir H, Molatseli P, Anderson J, Arens T, Fernandes J: Lactose malabsorption and gardiasis in Besotho school children. Acta Paediatr Scand 1987, 76(1):60-5.

19. Pettoello MM, Guandalini S, Ecuba P: Lactose malabsorption in children with symptomatic Giardia lamblia infection: feasibility of yogurt supplementation. J Pediatr Gastroenterol Nutr 1989, 9(3):295-300.

20. Bachou H, Tumwine JK, Mwadime RK, Thorkild T: Risk factors in hospital deaths in severely malnourished children in Kampala Uganda. BMC Pediatr 2006, 16(6):7

21. Kish Leslie: Survey Sampling. John Wiley and Sonsa; New York; 1965:59-50

\section{Pre-publication history}

The pre-publication history for this paper can be accessed here:

http://www.biomedcentral.com/1471-2431/10/31/prepub

doi: 10.1186/1471-2431-10-31

Cite this article as: Nyeko et al., Lactose intolerance among severely malnourished children with diarrhoea admitted to the nutrition unit, Mulago hospital, Uganda BMC Pediatrics 2010, 10:31

Submit your next manuscript to BioMed Central and take full advantage of:

- Convenient online submission

- Thorough peer review

- No space constraints or color figure charges

- Immediate publication on acceptance

- Inclusion in PubMed, CAS, Scopus and Google Scholar

- Research which is freely available for redistribution

Submit your manuscript at www.biomedcentral.com/submit
C) Biomed Central 